\title{
ORIGIN OF SUBSOIL CARBON IN A CHINESE PADDY SOIL CHRONOSEQUENCE
}

\author{
Tino Bräuer ${ }^{1}$ Pieter M Grootes • Marie-Josée Nadeau \\ Leibniz-Laboratory, Christian-Albrechts-University zu Kiel, Germany.
}

\begin{abstract}
Rice paddies are highly important agricultural soils in view of their relevance as major staple food provider in the world and their key role in the global carbon cycle, caused by special management practices. A soil chronosequence, consisting of paddy and upland soils, developed on reclaimed estuarine sediments in the Province of Zhejiang, China, was sampled to investigate the influence of duration of agricultural use (50 to $2000 \mathrm{yr}$ ) on soil composition. The uniform composition of the parent material provides the unique opportunity to compare the effects of different land management practices (paddy and non-paddy) on soil carbon dynamics and the origin of organic carbon (OC) in top- and subsoils, using ${ }^{14} \mathrm{C}$ measurements by accelerator mass spectrometry (AMS). The total soil organic carbon (TOC) was split into chemically defined pools of different mobility, namely the acid- and water-soluble fulvic acids (FA), the alkali-soluble humic acids (HA), and insoluble humin fraction. The more mobile HA and FA fractions contain significantly more ${ }^{14} \mathrm{C}$ than the corresponding TOC and humin, indicating a downward transport of OC in the subsoil. Plant roots with ${ }^{14} \mathrm{C}$ concentrations up to $128 \%$ of the modern standard, found far below the plough pan, reveal plant roots and root exudates as other direct sources of subsoil OC in paddy soils.
\end{abstract}

\section{INTRODUCTION}

Rice paddy soils are the most important agricultural soils in the world because (i) paddy soils provide the staple food for nearly half the world population (MacLean et al. 2002) and (ii) paddy soils play an important role in the global carbon and methane cycle. Rice is the major crop in the tropics and subtropics, whereas China represents the predominant rice producer with about $30 \%$ of the global rice production and $19 \%$ of the total world rice paddy area (FAOSTAT 2010). In the context of mitigating the increase of the atmospheric greenhouse gases $\mathrm{CO}_{2}$ and $\mathrm{CH}_{4}$, paddy soils are quite important in view of the high soil organic carbon (SOC) level observed in paddy topsoils, their assumed high C sequestration potential (Pan et al. 2003; Xu et al. 2011), and the amenability of their properties to active management. The larger paddy topsoil SOC stocks, compared to upland soils, are caused by a large carbon input via straw incorporation and/or other organic additions (Tanji et al. 2003; Rui and Zhang 2010). Furthermore, the water-logged conditions during flooded phases lead to decreased decomposition rates and enhance the accumulation of SOC (Huang and Sun 2006; Kögel-Knabner et al. 2010).

After the oceans, soils are the largest active pool within the global carbon cycle (Lal 2008). The SOC pool is twice the size of the atmospheric $\mathrm{C}$ pool and nearly 3 times the size of the biotic $\mathrm{C}$ pool (Lal 2004). The amount of organic carbon (OC) in the upper $100 \mathrm{~cm}$ in the world's soils is estimated to be about $1550 \mathrm{Pg}\left(1 \mathrm{Pg}=10^{15} \mathrm{~g}\right)$ (Batjes 1996). Since soils are the largest reservoir for $\mathrm{C}$ in the terrestrial ecosystem, they play a key role within the global carbon cycle, and SOC dynamics were examined in numerous studies of increasing organic complexity over the past decades (Scharpenseel et al. 1989; Trumbore et al. 1989; Becker-Heidmann and Scharpenseel 1992; Wang and Amundson 1996; Six et al. 2001; Baisden et al. 2002; Rethemeyer et al. 2005; Dreves et al. 2007; Flessa et al. 2008; Marschner et al. 2008; Laskar et al. 2012).

In many cases, only the topsoil $(\sim 0-30 \mathrm{~cm})$ of the related soil profile is considered. Although those upper $30 \mathrm{~cm}$ contain $<50 \%$ of the SOC (Jobbagy and Jackson 2000), the organic carbon located in subsoil horizons was assumed to be insignificant within the system of SOC transport and stabilization. Land-use-change related shifts in SOC stocks, for example, were assumed to be significant only in topsoils (O’Brien and Stout 1978; Baisden et al. 2002). The main reason for this point of

${ }^{1}$ Corresponding author. Email: tbraeuer@leibniz.uni-kiel.de.

(C) 2013 by the Arizona Board of Regents on behalf of the University of Arizona

Proceedings of the 21st International Radiocarbon Conference edited by A J T Jull \& C Hatté

RADIOCARBON, Vol 55, Nr 2-3, 2013, p 1058-1070 


\section{T Bräuer et al.}

view is the assumption that subsoil carbon is inert and does not take part in the dynamic interactions between different soil compartments. This is based on very low annual inputs of fresh organic matter and the limited spatial accessibility of subsoil OC for microbial activities and oxygen within the soil profile (Christensen 2001). Furthermore, in view of the low ${ }^{14} \mathrm{C}$ activity of subsoil horizons, it is assumed that, with increasing depth, SOC becomes more stabilized and shows longer residence times (Rumpel and Kögel-Knabner 2011).

In the course of the discussion about global warming and the potential of deep-soil OC as a sink for $\mathrm{CO}_{2}$, subsoil OC attracted more attention over the last decade, with more and more reports pointing out the role of subsoil OC within the dynamic system of SOC transport and stabilization (Trumbore 2000; Baisden and Parfitt 2007; Helfrich et al. 2011). Thus, subsoil OC seems to be less inert than commonly assumed, especially with the input of fresh OC in the subsoil priming microbial processes (Fontaine et al. 2007).

Suitable for investigating subsoil OC dynamics under paddy management are the large floodplains in the coastal zone of subtropical China. Paddy and non-paddy soils (upland soils not used for submerged rice cultivation) of different ages, developed on reclaimed estuarine sediments originating from the nearby Yangtze River, were sampled near Cixi in Zhejiang Province, China. Previous results of bulk soil samples documented the transport-induced development of TOC and ${ }^{14} \mathrm{C}$ depth gradients in the initially uniform upper $1 \mathrm{~m}$ of sediment, and demonstrated a replacement of old organic carbon by young OC by using the radioactive isotope ${ }^{14} \mathrm{C}$ as a tracer (Bräuer et al. 2013). Water is the most likely transport medium, so a simple OC partition in acid/water soluble, alkali/ water soluble, and water insoluble was chosen to further evaluate OC transport. This is the classical purification scheme of ${ }^{14} \mathrm{C}$ dating, where the insoluble, non-mobile fraction is generally chosen as the most reliable fraction for dating (e.g. Grootes et al. 2004), and closely resembles the classical separation in fulvic acids, humic acids, and humin of soil sciences. It serves to demonstrate OC transport by, and dynamic exchange of OC between, these fractions without the necessity to define specific processes and their relative importance (e.g. Kleber et al. 2007).

Elevated ${ }^{14} \mathrm{C}$ concentrations, connected with the atmospheric testing of nuclear weapons of the late 1950s and early 1960s, make it possible to demonstrate the presence of (sub)recent plant remains in the subsoil and the potential of roots and their exudates for introducing fresh OC into deep soil horizons. Identification of rice DNA in root material at $1 \mathrm{~m}$ depth in a paddy soil further documents rice root penetration deep below the plough pan. We here use ${ }^{14} \mathrm{C}$ concentrations of plant remains and of SOC fractions, characterized by different stability and mobility, to reveal the pathways of dynamic relocation of SOC into the subsoil and show that, despite the decoupling between topsoil and subsoil regarding OC accumulation (Wissing et al. 2011), subsoil OC dynamics is important for understanding the role of soils in the global carbon cycle.

\section{METHODS}

\section{Study Sites and Soil Sampling}

The study sites belong to one of the oldest paddy soil regions in the world (Cao et al. 2006). The soil samples were taken near the southern coast of Hangzhou Bay around Cixi, Zhejiang Province, China (Figure 1). With a mean annual temperature of $16.3^{\circ} \mathrm{C}$ and a mean precipitation of $1325 \mathrm{~mm}$ per year, the climate is classified as subtropical with periodical monsoon rain (Cheng et al. 2009). Estuarine sediment, which originates from the Yangtze River, represents the parent material of the study sites. Over the past centuries, protective dikes were built to establish arable land. This led to the development of differently aged soils formed on the same substrate under comparable conditions 
of climate, topography, and vegetation - the development of a soil chronosequence (Harden 1982). This circumstance allows us to study the uptake and relocation of OC with atmospheric ${ }^{14} \mathrm{C}$ composition on comparable sites established at different times. More detailed information about the study area and the historical development of the differently aged soils is given by Cheng et al. (2009) and Kalbitz et al. (2013).

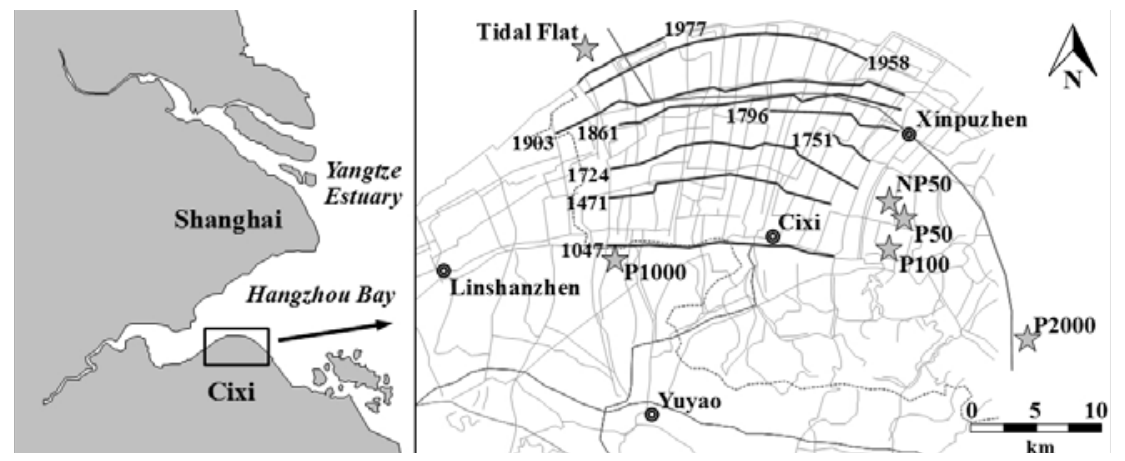

Figure 1 Geographical locations of the sampling sites at the south coast of Hangzhou Bay. To reclaim arable land, protective dikes, partly indicated by heavy black lines, were built. Years of dike construction are given next to the dike lines. Stars represent the position of sampling points (P 50, NP 50, P 100, P 1000, P 2000-yr old soil profiles, and tidal flat).

Soil horizons were described by the FAO Guidelines for Soil Description (FAO 2006) and classified according to IUSS Working Group WRB (2007). Paddy soil profiles were divided into topsoil and subsoil. Topsoils are represented by a puddle layer and plough pan (A-horizons) and obtain average depths between 20 and $25 \mathrm{~cm}$. The subsoils consist of several B-horizons. More detailed information regarding the soil profile description is given by Wissing et al. (2011). In addition to paddy (P) and non-paddy (NP) soils with different ages (50 and $2000 \mathrm{yr}$ ), tidal flat samples (estuarine sediment) were taken. The latter represent the parent material from which soils developed in this region.

\section{Sample Preparation}

All soil samples were air-dried and sieved through 2-mm mesh size to homogenize the material. Nonsoil-derived particles as well as identifiable plant residues were removed and kept for further studies.

\section{Chemical Extraction}

Soil samples were treated with $4 \mathrm{~mL}$ dilute (1\%) hydrochloric acid $(\mathrm{HCl})$ per gram of soil to remove carbonates, and freeze-dried without washing to determine their TOC content and TOC ${ }^{14} \mathrm{C}$ concentration. Furthermore, tidal flat, 50- and 2000-yr-old soil samples underwent chemical fractionation by acid-alkali-acid (AAA) extraction. AAA in air is a standard method in ${ }^{14} \mathrm{C}$ dating to remove contaminating carbon from organic samples (charcoal, plant remains, etc.) prior to ${ }^{14} \mathrm{C}$ measurements (Grootes et al. 2004). The application of AAA is similar to the classical humus fractionation procedure according to Stevenson (1994), resulting in 3 fractions: the acid-soluble fulvic acid (FA); the alkali-soluble humic acid (HA); and the insoluble humin fraction (alkali residue).

Dried soil samples were treated with diluted (1\%) $\mathrm{HCl}$ for $>10 \mathrm{hr}$ to remove carbonates. The yellowish supernatant, containing acid-soluble compounds (FA), was separated. The pellet was washed with Milli- $\mathrm{Q}^{\mathrm{TM}}$ water until $\mathrm{pH}>4$ to remove the hydrochloric acid and dissolved contaminants. Samples were then extracted with $1 \% \mathrm{NaOH}$ for $4 \mathrm{hr}$ at $60^{\circ} \mathrm{C}$. This yields an alkali-soluble fraction 


\section{T Bräuer et al.}

and a non-soluble residue (humin). Humic acids were precipitated from the alkaline solution by acidification with $37 \% \mathrm{HCl}$ down to $\mathrm{pH}<1$ and washed until $\mathrm{pH}>4$ as above. In several cases, the supernatant was kept to recover acid-soluble FAs. The insoluble residue (humin fraction) was washed with Milli-Q water until $\mathrm{pH}<10$. To remove any atmospheric $\mathrm{CO}_{2}$ introduced during the alkali treatment, the humin fraction was again treated with $1 \% \mathrm{HCl}$ and washed until $\mathrm{pH}>4$. All extracts, fulvic acids, humic acids, and humin fractions were freeze-dried.

\section{Macrofossils (Plant Remains, Roots)}

To obtain identifiable macrofossils, water was added to large soil samples ( $\sim \mathrm{kg})$ and plant remains were separated by elutriation and sieving (400- $\mu \mathrm{m}$ mesh size). The sieved material was inspected under a microscope and non-plant components (stones, shells, etc.) were removed. Selected plant samples were subjected to the AAA treatment described above.

\section{Isolation of Genomic DNA and 18S rDNA Analysis}

To test whether rice plant roots reach below the plough pan, root material found at depth was tested for rice DNA by Dr Nancy Weiland-Bräuer at the Institute of Microbiology, Christian-Albrechts Universität zu Kiel (CAU). Twenty samples of root material were used for genomic DNA extraction according to Doyle and Doyle (1987) with modifications. Plant parts (300 mg) were resuspended in CTAB buffer (140 mM sorbitol, 220 mM Tris, 22 mM EDTA, $800 \mathrm{mM} \mathrm{NaCl,} \mathrm{1 \%} \mathrm{sarkosyl,} \mathrm{0.8 \%}$ CTAB, $\mathrm{pH} 8.0)^{2}$ and glass beads of 0.1-, 0.5-, and 2.5-mm size were added prior to the mechanical cell disruption for 9 min at 1300 strokes/min (GenoGrinder ${ }^{\circledR}$; BT\&C/OPS Diagnostics, Bridgewater, USA). Chloroform extraction of the supernatant was performed followed by precipitation of the nucleic acids with isopropanol $(0.7 \mathrm{vol})$ for $20 \mathrm{~min}$ at room temperature and subsequent centrifugation for $1 \mathrm{hr}$ at $16,000 \times \mathrm{g}$ and $4{ }^{\circ} \mathrm{C}$. The DNA precipitate was washed twice with $70 \%$ ethanol and resuspended in $15 \mu \mathrm{L}$ Tris-EDTA buffer (10 mM Tris, 1 mM EDTA, pH 8.0).

The 18S rDNA gene fragments were amplified in a standard PCR (polymerase chain reaction) using 50 ng isolated genomic DNA, GoTaq ${ }^{\circledR}$ polymerase (Promega, Mannheim/Germany) and primer set 18S_FW (5'-AGGAATTGACGGAAGGGCAC-3') and 18S_RV (5'-GGACATCTAAGGGCATCACA-3’) (Luan et al. 2005). Reaction mixtures were incubated in a PT-100 thermal cycler ${ }^{\circledR}$ (MJ Research Inc., Waltham, USA) at $94^{\circ} \mathrm{C}$ for $5 \mathrm{~min}$, followed by 30 cycles at $94{ }^{\circ} \mathrm{C}$ for $30 \mathrm{~s}, 50{ }^{\circ} \mathrm{C}$ for $45 \mathrm{~s}$, and $72^{\circ} \mathrm{C}$ for $30 \mathrm{~s}$, resulting in a 324 bp PCR fragment. DNA sequences of PCR products were determined completely by the sequencing facility at the Institute of Clinical Molecular Biology, CAU (IKM). Sequences were compared to available databases using the BLAST (Basic Local Alignment Search Tool) network service (Altschul et al. 1990) to determine their approximate phylogenetic affiliations.

\section{Sample Treatment for AMS}

After freeze-drying, sample aliquots were transferred into precombusted $\left(4 \mathrm{hr}, 900{ }^{\circ} \mathrm{C}\right)$ quartz tubes, evacuated, subsequently flame-sealed, and combusted with $\mathrm{CuO}$ (450 mg) and silver wool (150 mg) at $900{ }^{\circ} \mathrm{C}$ for $4 \mathrm{hr}$. The resulting $\mathrm{CO}_{2}$ was reduced to graphite with $\mathrm{H}_{2}$ at $600{ }^{\circ} \mathrm{C}$ over an iron catalyst. The ${ }^{14} \mathrm{C}$ measurements were made with the 3MV HVE Tandetron AMS (accelerator mass spectrometry) system at the Leibniz-Laboratory in Kiel (Germany), with a $1 \sigma$ precision of $\sim 0.25$ pMC (Nadeau et al. 1997, 1998). ${ }^{14} \mathrm{C}$ values are stated in percent modern carbon (pMC) and were calculated from the measured ${ }^{14} \mathrm{C} /{ }^{12} \mathrm{C}$ ratios of the sample and the oxalic acid standard according to Stuiver and Polach (1977).

\footnotetext{
${ }^{2}$ Tris: tris(hydroxymethyl)aminomethane; EDTA: ethylenediaminetetraacetic acid; CTAB: cetrimonium bromide.
} 
Origin of Subsoil C in a Chinese Paddy Soil

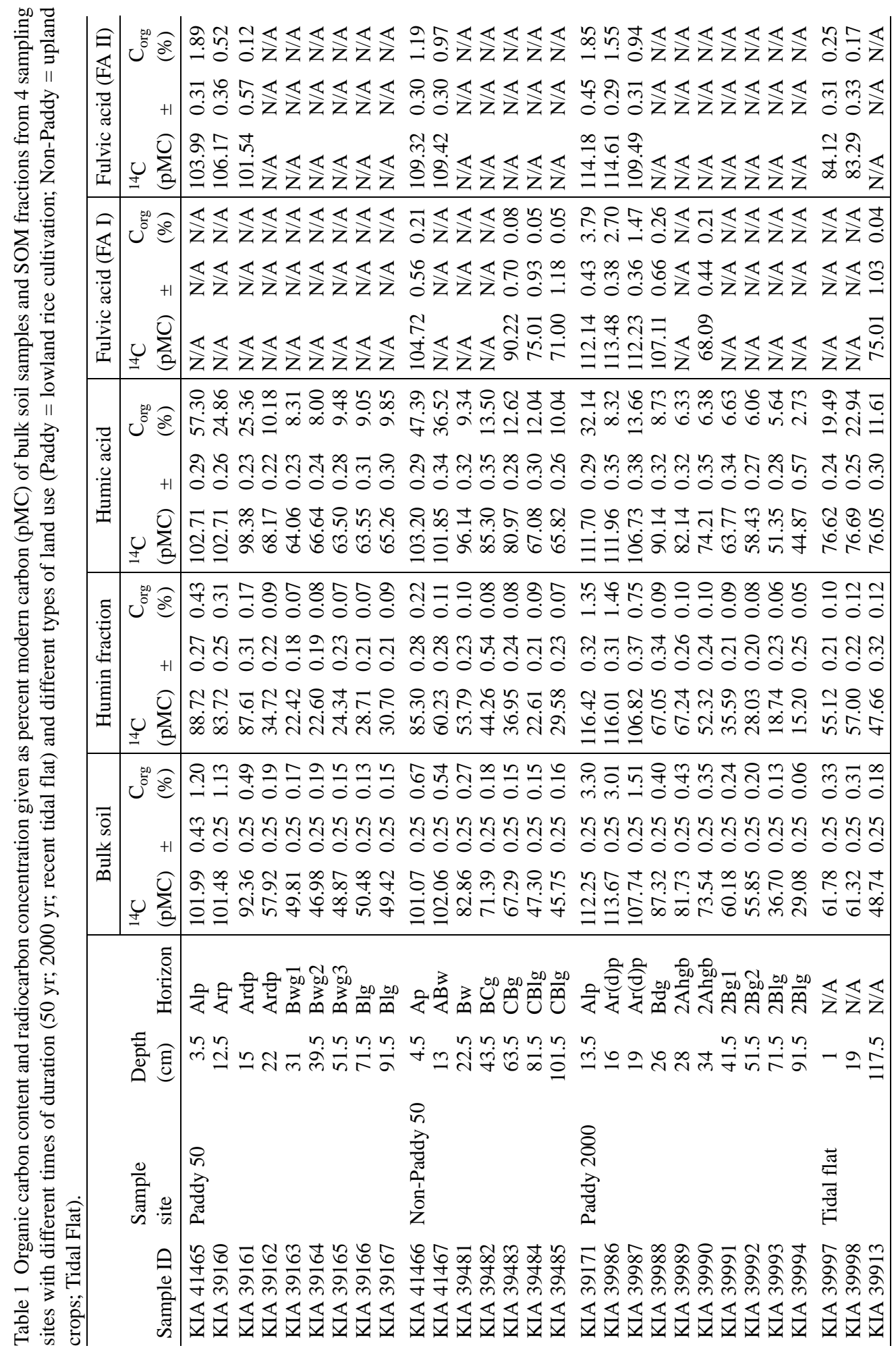




\section{T Bräuer et al.}

\section{RESULTS AND DISCUSSION}

\section{Depth Gradients of ${ }^{14} \mathrm{C}$ in Chemical Soil Organic Matter (SOM) Fractions}

The ${ }^{14} \mathrm{C}$ concentrations of TOC (Bräuer et al. 2013) and the 3 corresponding chemical fractions humin, humic acid, and fulvic acid are given as a function of depth for the 50-yr-old paddy (P50), non-paddy soil (NP50), and the 2000-yr-old paddy soil (P2000) in Figure 2a-c and Table 1, together with the values obtained for the sediment of the tidal flat. The results clearly show the age inhomogeneity of the TOC, with the insoluble humin fraction consistently older, and the more mobile humic acids younger than the TOC. The measured fulvic acids have, with 1 exception, a higher ${ }^{14} \mathrm{C}$ concentration than the humic acids. In P50, the striking drop in ${ }^{14} \mathrm{C}$ concentration across the plough pan (horizon Ardp), already observed for TOC (Bräuer et al. 2013), is also seen in the chemical fractions (Figure 2a). The development of their ${ }^{14} \mathrm{C}$ concentrations with depth is very similar. The NP50 shows a more or less constant decrease in ${ }^{14} \mathrm{C}$ with depth for all SOC fractions, comparable to ${ }^{14} \mathrm{C}$ gradients reported by Scharpenseel et al. (1989) and Paul et al. (1997). Thus, the decoupling of topsoil from subsoil by plough pan development under rice paddy management clearly affects all SOC fractions in the subsoil and delays the buildup of the customary ${ }^{14} \mathrm{C}$ or "age"-depth profile beyond 50 yr. After 2000 yr, such a profile is also found in the paddy subsoil (Figure 2c).

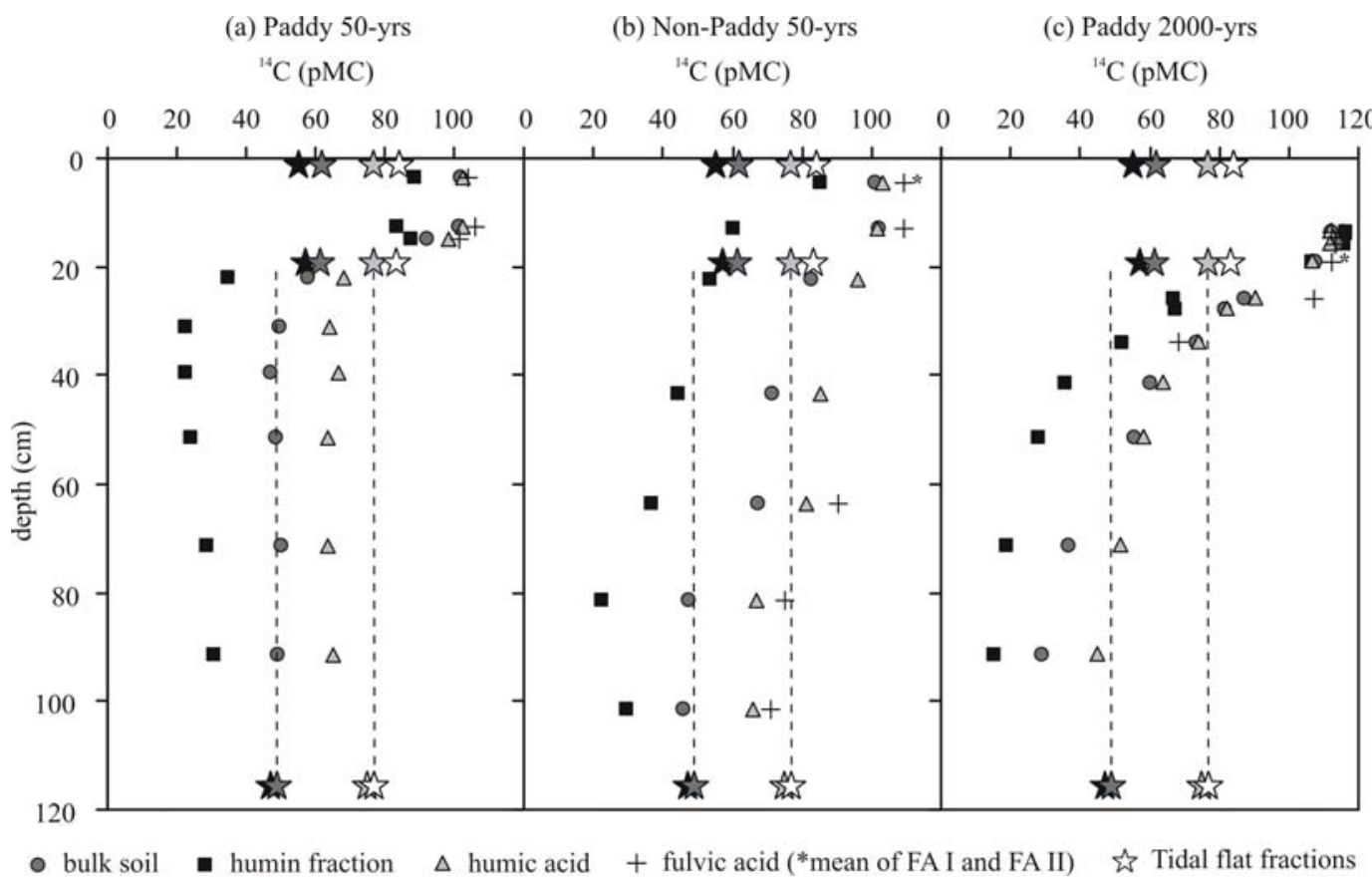

Figure $2{ }^{14} \mathrm{C}$ concentrations of bulk soil samples and the corresponding SOM fractions (humin, humic acid, fulvic acid) for P50, NP50, and P2000. The stars display ${ }^{14} \mathrm{C}$ concentrations of the parent material, represented by tidal flat samples from depths of 0-2, 18-20, and 115-120 cm (black: humin fraction; dark gray: bulk soil; light gray: humic acid; white: fulvic acid). ${ }^{14} \mathrm{C}$ measurement uncertainties are smaller than the symbol sizes.

After 50 yr of cultivation, bulk soil samples from the topsoil of both the paddy and non-paddy gave ${ }^{14} \mathrm{C}$ contents above $100 \mathrm{pMC}$, close to the atmospheric ${ }^{14} \mathrm{CO}_{2}$ level (105 pMC) in 2008, the year of sampling (Levin et al. 2010; Graven et al. 2012). This indicates that, already after 50 yr, a high proportion of the original OC of the tidal flat sediments, with $\sim 61 \mathrm{pMC}$, had been replaced with OC 


\section{Origin of Subsoil C in a Chinese Paddy Soil}

derived from recent atmospheric photosynthesis products. Both P50 and NP50 topsoils show comparable ${ }^{14} \mathrm{C}$ concentrations for all SOC fractions. The humin fraction, with ${ }^{14} \mathrm{C}$ values around $85 \mathrm{pMC}$, still clearly shows the influence of the original OC. The rapid ${ }^{14} \mathrm{C}$ increase in this relatively stable fraction may be due more to the increase in TOC and humin OC in the paddy topsoil than to replacement. All topsoil fractions of P2000 are characterized by ${ }^{14} \mathrm{C}$ values significantly higher than those of the P50 and NP50 sites (Table 1). The high ${ }^{14} \mathrm{C}$ and TOC values can be assigned to the accumulation of plant-derived carbon during the last several decades. Interestingly, the humin fraction, which is assumed to be the most stable part of SOC, shows the highest modern ${ }^{14} \mathrm{C}$ concentrations within the uppermost $15 \mathrm{~cm}$ (116.4 pMC in horizon Alp). These values, which exceed the atmospheric ${ }^{14} \mathrm{C}$ level in 2008, indicate the contribution of OC from the last 40 to $50 \mathrm{yr}$ (average ${ }^{14} \mathrm{CO}_{2}=$ $116.6 \mathrm{pMC}$ in 1989). The ${ }^{14} \mathrm{C}$ concentrations of the humic and fulvic acids in the P2000 topsoil, (slightly) below those of the TOC though still well above the atmosphere of 2008, suggest these derive on average from more recent decomposition of organic material.

The observed decrease in ${ }^{14} \mathrm{C}$ in the humin fraction with increasing soil depth is commonly observed and has been interpreted in previous reports by Balesdent (1987), Pessenda et al. (2001), and Rethemeyer et al. (2005) as aging and a relative increase of recalcitrant organic compounds in the humin fraction (Rice 2001). Yet, in the case of this chronosequence, it documents the replacement of the original estuarine OC by younger components moving down the soil profile, presumably as DOC, and then becoming incorporated in the humin fraction. Right below the P2000 plough pan with $116 \mathrm{pMC}$, the humin fraction shows $67 \mathrm{pMC}$, already indicating mostly aged, recalcitrant SOC with an apparent age of $\sim 3000{ }^{14} \mathrm{C}$ yr, yet almost $20 \mathrm{pMC}$ enriched in ${ }^{14} \mathrm{C}$ compared to the original estuarine sediments of the tidal flat.

The humin fraction shows ${ }^{14} \mathrm{C}$ contents lower than those of the initial tidal flat sediment at depth in all profiles (Figure 2). The decrease is too large to be caused by natural decay, even in $2000 \mathrm{yr}$, which would reduce the $47.6 \mathrm{pMC}$ of the deep tidal flat to $37.4 \mathrm{pMC}$. Instead, the low ${ }^{14} \mathrm{C}$ concentrations of the deep humin fractions may reflect the effect of a supply of fresh OC to a subsoil containing a mixture of organic material, in part old, reworked, and in part contemporaneous with the time of sedimentation (Bräuer et al. 2013). With measured ${ }^{14} \mathrm{C}$ concentrations in the deep tidal flat close to $50 \mathrm{pMC}$, the contemporaneous fraction must be at least $50 \%$ of the bulk and humin OC. The values close to $23 \mathrm{pMC}$ at 30 to $40 \mathrm{~cm}$ in P50, and around $80 \mathrm{~cm}$ in NP50, as well as the values below 20 pMC in P2000 below $70 \mathrm{~cm}$ (Table 1), indicate only 23\% or less "young” OC remained in these humin fractions, which means that $65 \%$ or more of the younger components of the estuarine OC mixture were preferentially degraded and lost. Interestingly, in P50, where the ploughpan still has blocked most of the downward transport of OC, the minimum ${ }^{14} \mathrm{C}$ concentration is found closely below this ploughpan, while in NP50 and P2000 minimum concentrations are found at depth, near the groundwater table. This suggests a relatively rapid preferential degradation of younger OC stimulated by a supply of fresh OC ("priming") and a gradual buildup of more recalcitrant young OC. The $\sim 50 \mathrm{pMC}$ still found at depth in the tidal flat may then reflect absence of vegetation and anoxic conditions.

The extracted FAs differ in ${ }^{14} \mathrm{C}$ concentration from the humic acids and the humin, and show small, yet significant differences before and after alkali treatment. In the P2000 topsoil, the ${ }^{14} \mathrm{C}$ of all FAs is above that of the 2008 atmosphere (105 pMC, Levin et al. 2010; Graven et al. 2012); in NP50 this is only true for FA II, while in P50 only one FA II exceeds the atmosphere. With the exception of the Bdg horizon at $26 \mathrm{~cm}$ in P2000, the FAs in the subsoil have a ${ }^{14} \mathrm{C}$ concentration below $100 \mathrm{pMC}$. In the P2000 topsoil, the ${ }^{14} \mathrm{C}$ in FA II is higher than in FA I at 13.5 and $16 \mathrm{~cm}$ depth (Table 1) and closer to the humin fraction from which it was separated. At $19 \mathrm{~cm}$, FA II has less ${ }^{14} \mathrm{C}$ than FA I and, thus, 


\section{T Bräuer et al.}

is again closer to the humin fraction. This apparent link between FA II and the humin fraction seems broken in the NP50 topsoil, where FA II shows a ${ }^{14} \mathrm{C}$ concentration well above that of the 2008 atmosphere, although all other fractions are below it. This seemingly erratic pattern may be ascribed to the diverse components of the organic mixture. The starting material was a mixture of old, reworked OC and young OC with a ${ }^{14} \mathrm{C}$ concentration, presumably, close to $100 \mathrm{pMC}$, to which plant material was added over the years with ${ }^{14} \mathrm{C}$ concentrations increasing irregularly from $98 \mathrm{pMC}$ in 1954 to 180 pMC in 1964 and then gradually dropping to 105 pMC in 2008 (Levin et al. 2010; Graven et al. 2012). This is reflected in the high pMC values of the humin fraction in the P2000 topsoil, indicating OC on average a few decades old with high bomb- ${ }^{14} \mathrm{C}$ concentrations. The FA I fraction is fairly small (Figure 3) and contains readily accessible and exchangeable components (Kleber et al. 2007) with a ${ }^{14} \mathrm{C}$ closer to the recent atmosphere.

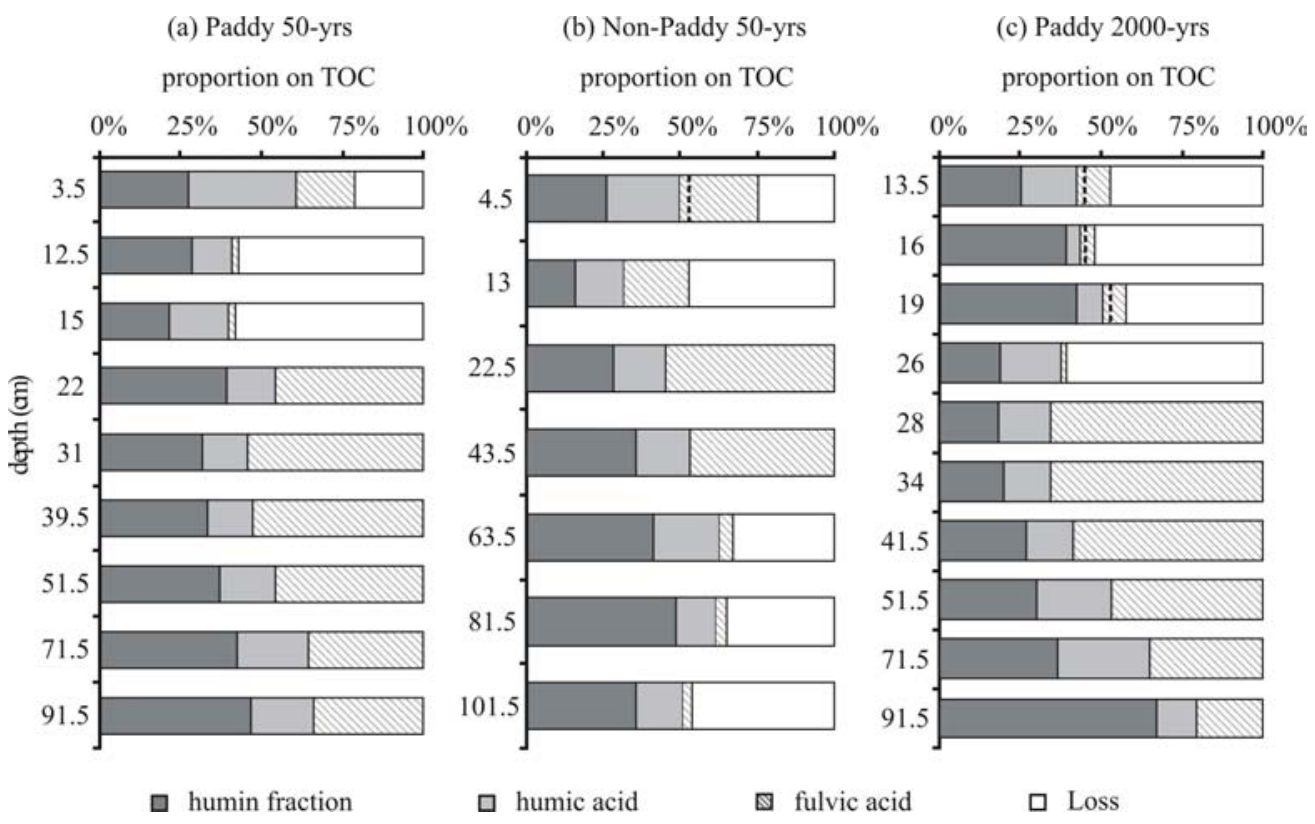

Figure 3 The proportions of single SOM fractions on the total organic carbon (TOC) given in percent. Quantification of humic acids and humin fraction yields fulvic acids (FA) as a difference with TOC. The FA of samples without a stated loss was calculated from the TOC, humin, and HA fraction amounts and not isolated. The mass balance for samples, from which FAs were extracted for ${ }^{14} \mathrm{C}$ measurement, is incomplete due to material loss during wet chemistry sample preparation. In cases where both FA fractions, before (FA I) and after alkali treatment (FA II), were recovered, FA II always delivers proportions on TOC at least 2 times (maximum $6 \times$ ) higher than FA I.

\section{Relative Importance of Mobile Fractions}

The relative contributions of the SOC fractions to the TOC are given in Figure 3. As described in the Methods section, the humin fraction is what remains after AAA extraction. The humic acid fraction is precipitated from the alkali extract with acid and washed until free of acid and soluble organic compounds. Quantification of the humic acids and the humins generally yields calculated fulvic acid (FA) contents as the difference with TOC (Figure 3). Direct recovery of the complete fulvic acid fraction is difficult, since it requires collection of all water used in the various washings. In a number of cases, fulvic acids were recovered by freeze-drying the first acid extract (FA I) and the acid supernatant after precipitation of the humic acid fraction from the alkali extract (FA II). For practical reasons, the subsequent, ever more diluted, washings were not included. The isolated ful- 
vic acids thus represent only a fraction of the TOC not accounted for by the humin and humic acid fractions (10 to $50 \%$ for FA I plus FA II, Figure 3). The missing material was assigned to the fulvic acid fraction, although it may include some fine colloidal material, which chemically does not belong to the fulvic acids. Interestingly, FA II generally contains more OC than FA I. While slightly acidic water can mobilize only a small fraction of the available SOC, as generally observed, the $4 \mathrm{hr}$ of alkaline extraction at $60{ }^{\circ} \mathrm{C}$ apparently loosens chemically bound compounds (e.g. Kleber et al. 2007), many of them belonging to the fulvic acid fraction, which were resisting the acidic solution.

With an average contribution of close to $50 \%$ of the TOC, the so-defined FAs constitute the main SOC fraction in each profile. The average contribution of the humic acid fraction is $<20 \%$ for all soil profiles, while the humin fraction represents $\sim 30 \%$ of the TOC. The importance of the insoluble humin fraction increases with increasing depth (Figure 3), up to 47\% of TOC at depth in P50 and $67 \%$ in P2000, but only 36\% in NP50. Since both TOC and the humin fraction decrease strongly with depth, especially from plough pan to subsoil (e.g. Table 1, TOC from 1.2\% C in the P50 topsoil to $0.14 \% \mathrm{C}$ at depth, from $3.3 \% \mathrm{C}$ in the $\mathrm{P} 2000$ topsoil to $~ 0.1 \%$ at depth), this relative increase reflects a very strong decrease in the more mobile fractions, especially in the FAs, in the subsoil. The TOC in the deeper subsoil is more or less the same in all 3 profiles (P50, NP50, and P2000) and similar to, or slightly lower than, that in the deep tidal flat. The same is true for the 3 humin fractions, which are, however, reduced relative to the tidal flat. The carbon mass balance thus provides the picture of strongly decreasing mobile components and little change in the subsoil that led to the neglect of subsoil processes.

The buildup of ${ }^{14} \mathrm{C}$ concentration profiles in the originally homogeneous, ${ }^{14} \mathrm{C}$-depleted sediment of the subsoil documents, however, the downward transport of SOC, presumably as dissolved organic carbon (DOC), with infiltrating water. FAs are of major importance for this transport of OC through the soil profile as indicated by their high proportion, especially within the transition zone from plough pan to subsoil. Maie et al. (2004) reported chemical characteristics of FAs leached from the plough layer of a paddy soil, where the FA fraction was up to $56 \%$ of the OC. The liberation of FAs by alkali extraction and the parallel behavior of the ${ }^{14} \mathrm{C}$-depth curves for humins, humic acids, and fulvic acids (Figure 2) suggest a dynamic exchange between these 3 SOC fractions and a likely role of the mobile FA and HA fractions as main driver for the described refreshment of SOC pools below plough pan level by organic matter with a younger ${ }^{14} \mathrm{C}$ signature.

\section{Plant Remains: Another Pathway of OC Transport into Subsoil}

In addition to visual methods, molecular biological methods were applied to identify plant remains found deep in soil profiles. This is particularly useful when only parts of plants are available. The characterization is based on isolation of genomic plant DNA and subsequent amplification of the 18S rDNA fragment with specific primers in a PCR. Plant remains recovered by wet-sieving from all depths of the soil profiles were differentiated by morphological means. Most of these plantderived macrofossils were found in the topsoil of each profile. The assemblage consists of seeds, spelts, and grains of several species like millet, wheat, barley, or rice. Furthermore, straw, rice hulls, roots, and charcoals were found. Collecting such plant remains below the plough pan was more difficult due to their rare occurrence. Most of the plant remains found in deep soil horizons could be identified visually only as roots or rather root remains and root mats. Thus, classification into a species by visual means was not possible. DNA extraction and analysis identified 1 out of 20 root samples as rice (Oryza sativa), indicating rice root penetration below the plough pan to a surprising depth of 97-100 cm (Table 2). 


\section{T Bräuer et al.}

Rice is often described as a shallow-rooting crop with roots mostly located above the plough pan, which restricts deep-rooting growth (Wade et al. 1999). Yet, Mishra et al. (1997) reported a maximum rooting depth between 55 and $65 \mathrm{~cm}$, depending on water table conditions. The rooting depth is assumed to be influenced by the prevalent water regime, so dry-land varieties are characterized by deeper rooting depths, while submerged rice plant varieties tend to be shallow-rooted (Yoshida and Hasegawa 1982). Soil cracks that develop when the soil dries out facilitate root penetration below the plough pan. Thus, the presence of roots, including those of rice, is not totally unexpected and indicates that young carbon may be inserted directly into the subsoil as root material and root exudates.

Table 2 Radiocarbon and organic carbon contents of plant remains (roots and root mats) selected from deep subsoil horizons of different aged paddy soils. The table includes also ${ }^{14} \mathrm{C}$ data of plant remains of 100- and 1000-yr-old paddy soils. No data are available for the P2000 soil profile. The presented data belong to the samples that were used for DNA analysis.

\begin{tabular}{llllll} 
Sample ID & Sample site & Horizon & $\begin{array}{l}\text { Sampled depth } \\
(\mathrm{cm})\end{array}$ & $\begin{array}{l}{ }^{14} \mathrm{C} \\
(\mathrm{pMC})\end{array}$ & $\begin{array}{l}\mathrm{C}_{\text {org }} \\
(\%)\end{array}$ \\
\hline KIA 39164 & Paddy 50 & Bwg2 & $38-41$ & $112.08 \pm 0.47$ & 52.34 \\
KIA 39166 & Paddy 50 & Blg & $70-73$ & $119.57 \pm 1.03$ & 48.44 \\
KIA 40291 & Paddy 100 & Bwlg1 & $72-75$ & $110.08 \pm 0.46$ & 37.11 \\
KIA 40292 & Paddy 100 & Bwlg2 & $97-100$ & $127.57 \pm 0.75$ & 41.88 \\
KIA 40324 & Paddy 1000 & 3Bl & $107-110$ & $118.34 \pm 0.33$ & 49.28 \\
\hline
\end{tabular}

${ }^{a}$ This is the only sample that could be identified as rice (Oryza sativa).

Although the roots formed a root mat, it cannot be excluded that plant and root remains were relocated down by bioturbation, since canals and holes of up to several mm diameter as well as living earthworms as indicators for bioturbation activity were observed during sampling across the entire soil profile. Recent studies identified such macropore systems as flow paths, and therefore revealed crack and root channels as well as earthworm burrows as responsible for water loss and solute leaching (Janssen and Lennartz 2008; Lennartz et al. 2009).

\section{CONCLUSIONS}

Soil profiles from a chronosequence of plots under paddy and non-paddy management formed on the same uniform ${ }^{14} \mathrm{C}$-depleted estuarine sediments reveal the rapid development of ${ }^{14} \mathrm{C}$ and TOC gradients in the subsoil as a result of organic carbon mobility and relocation. The following are the processes of subsoil "OC refreshing” indicated by ${ }^{14} \mathrm{C}$ concentrations:

1. Direct input of fresh (modern) SOC into deep subsoil by plant roots and their exudates. This process is evident by roots and root remains, including rice roots identified by their DNA signature, with modern ${ }^{14} \mathrm{C}$ signature found far below the plough pan in deep soil horizons.

2. Relocation and transport of young OC through the plough pan via mobile SOC fractions (humic acids and fulvic acids). Due to their high proportion on total organic carbon, we assume fulvic acids to be the main driver for the input of OC through the plough pan into the subsoil.

3. Downward movement of plant remains into the subsoil through animal activity and soil cracking.

Despite this input of fresh organic material, OC concentrations in the subsoil remain largely constant over the chronosequence, while the ${ }^{14} \mathrm{C}$ concentration increases. The composition of subsoil OC down to the $1 \mathrm{~m}$ depth of this investigation is thus determined by a dynamic equilibrium between the import of fresh OC, mineralization, and export into groundwater and deeper subsoil. 
Origin of Subsoil C in a Chinese Paddy Soil

\section{ACKNOWLEDGMENTS}

We thank the German Research Foundation (DFG) for funding this project as part of the Research Unit 995 "Biogeochemistry of Paddy Soil Evolution." The authors also gratefully acknowledge the support of Prof Z-H Cao (Institute of Soil Science, Chinese Academy of Sciences, Nanjing), who provided the chance to work on the described soil chronosequence and the assistance in the analyses of the team of the Leibniz-Laboratory. Furthermore, we thank Dr Nancy Weiland-Bräuer (Institute of Microbiology, CAU Kiel) for her support during sample DNA preparation and sequencing, and a reviewer for constructive comments.

\section{REFERENCES}

Altschul S, Gish W, Miller W, Myers E, Lipman D. 1990. Basic local alignment search tool. Journal of Molecular Biology 215(3):403-10.

Baisden WT, Parfitt RL. 2007. Bomb ${ }^{14} \mathrm{C}$ enrichment indicates decadal C pool in deep soil? Biogeochemistry 85(1):59-68.

Baisden WT, Amundson R, Brenner DL, Cook AC, Kendall C, Harden JW. 2002. A multiisotope C and N modeling analysis of soil organic matter turnover and transport as a function of soil depth in a California annual grassland soil chronosequence. Global Biochemical Cycles 16(4):8210-26.

Balesdent J. 1987. The turnover of soil organic fractions estimated by radiocarbon dating. The Science of the Total Environment 62:405-8.

Batjes NH. 1996. Total carbon and nitrogen in the soils of the world. European Journal of Soil Science 47: 151-63.

Becker-Heidmann P, Scharpenseel HW. 1992. Studies of soil organic matter dynamics using natural carbon isotopes. The Science of the Total Environment 117/118: 305-12.

Bräuer T, Grootes PM, Nadeau MJ, Andersen N. 2013. Downward carbon transport in a 2000-year rice paddy soil chronosequence traced by radiocarbon measurements. Nuclear Instruments and Methods in Physics Research B 294:584-7.

Cao ZH, Ding JL, Hu ZY, Knicker H, Kögel-Knabner I, Yang LZ, Yin R, Lin XG, Dong YH. 2006. Ancient paddy soils from the Neolithic age in China's Yangtze River Delta. Naturwissenschaften 93(5):232-6.

Cheng YQ, Yang LZ, Cao ZH, Yin S. 2009. Chronosequential changes of selected pedogenic properties in paddy soils as compared with non-paddy soils. Geoderma 151:31-41.

Christensen BT. 2001. Physical fractionation of soil and structural and functional complexity in organic matter turnover. European Journal of Soil Science 52:34553.

Doyle JJ, Doyle JL. 1987. A rapid DNA isolation procedure for small quantities of fresh leaf tissue. Phytochemistry Bulletin 19:11-5.

Dreves A, Andersen N, Grootes PM, Nadeau M-J, Garbe-Schönberg CD. 2007. Colloidal matter in water extracts from forest soils. Environmental Chemistry
4(6):424-9.

FAO. 2006. Guidelines for Soil Description. Rome: FAO. 97 p.

FAOSTAT (Food and Agricultural Organization of the United Nations). 2010. URL: http://faostat.fao.org/.

Flessa H, Amelung W, Helfrich M, Wiesenberg GLB, Gleixner G, Brodowski S, Rethemeyer J, Kramer C, Grootes PM. 2008. Storage and stability of organic matter and fossil carbon in a Luvisol and Phaeozem with continuous maize cropping: a synthesis. Journal of Plant Nutrition \& Soil Science 171:36-51.

Fontaine S, Barot S, Barre P, Bdioui N, Mary B, Rumpel C. 2007. Stability of organic carbon in deep soil layers controlled by fresh carbon supply. Nature 450(7167): 277-80.

Graven HD, Guilderson TP, Keeling RF. 2012. Observations of radiocarbon in $\mathrm{CO}_{2}$ at seven global sampling sites in the Scripps flask network: analysis of spatial gradients and seasonal cycles. Journal of Geophysical Research 117: D02303, doi:10.1029/2011JD016535.

Grootes PM, Nadeau MJ, Rieck A. 2004. ${ }^{14}$ C-AMS at the Leibniz-Labor: radiometric dating and isotope research. Nuclear Instruments and Methods in Physics Research B 223-224:55-61.

Harden JW. 1982. A quantitative index of soil development from field descriptions: examples from a chronosequence in central California. Geoderma 28:1-28.

Helfrich M, Flessa H, Ludwig B. 2010. Modelling carbon dynamics in subsoils using simple models. Journal of Plant Nutrition and Soil Science 173(5):671-7.

Huang Y, Sun W. 2006. Changes in topsoil organic carbon of croplands in mainland China over the last two decades. Chinese Science Bulletin 51(15):1785-803.

IUSS Working Group WRB. 2007. World Reference Base for Soil Resources. World Soil Resources Reports, Volume 103. Rome: FAO. 145 p.

Janssen M, Lennartz B. 2008. Characterization of preferential flow pathways through paddy bunds with dye tracer tests. Soil Science Society of America Journal 72(6):1756-66.

Jobbagy EG, Jackson RB. 2000. The vertical distribution of soil organic carbon and its relation to climate and vegetation. Ecological Applications 10(2):423-36.

Kalbitz K, Kaiser K, Fiedler S, Kölbl A, Amelung W, Bräuer T, Cao ZH, Don A, Grootes PM, Jahn R, 


\section{T Bräuer et al.}

Schwark L, Vogelsang V, Wissing L, Kögel-Knabner I. 2013. The carbon count of 2,000 years of rice cultivation. Global Change Biology 19(4):1107-13.

Kleber M, Sollins P, Sutton R. 2007. A conceptual model of organo-mineral interactions in soils: self-assembly of organic molecular fragments into zonal structures on mineral surfaces. Biogeochemistry 85:9-24.

Kögel-Knabner I, Amelung W, Cao ZH, Fiedler S, Frenzel P, Jahn R, Kalbitz K, Kölbl A, Schloter M. 2010. Biogeochemistry of paddy soils. Geoderma 157:1-14.

Lal R. 2004. Soil carbon sequestration impacts on global climate change and food security. Science 304(5677): 1623-6.

Lal R. 2008. Carbon sequestration. Philosophical Transactions of the Royal Society B 363:815-30.

Laskar AH, Yadava MG, Ramesh R. 2012. Radiocarbon and stable isotopes in two soil profiles from northeast India. Radiocarbon 54(1):81-9.

Lennartz B, Horn R, Duttmann R, Gerke HH, Tippkötter R, Eickhorst T, Janssen I, Janssen M, Rüth B, Sander T, Shi X, Sumfleth K, Taubner H, Zhang B. 2009. Ecological safe management of terraced rice paddy landscapes. Soil \& Tillage Research 102:179-92.

Levin I, Naegler T, Kromer B, Diehl M, Francey RJ, Gomez-Pelaez AJ, Steele LP, Wagenbach D, Weller R, Worthy DE. 2010. Observations and modeling of the global distribution and long-term trend of atmospheric ${ }^{14} \mathrm{CO}_{2}$. Tellus $B$ 62:26-46.

Luan YX, Mallatt JM, Xie RD, Yang YM, Yin WY. 2005. The phylogenetic positions of three basal-hexapod groups (Protura, Diplura, and Collembola) based on ribosomal RNA gene sequences. Molecular Biology and Evolution 22:1579-92.

MacLean JL, Dawe DC, Hardy B, Hettel GP. 2002. Rice Almanac: Source Book for the Most Important Economic Activity on Earth. Wallingford: CABI Publishing. $270 \mathrm{p}$.

Maie N, Watanabe A, Kimura M. 2004. Chemical characteristics and potential source of fulvic acids leached from the plow layer of paddy soil. Geoderma 120: 309-23.

Marschner B, Brodowski S, Dreves A, Gleixner G, Gude A, Grootes PM, Hamer U, Heim A, Jandl G, Ji R, Kaiser K, Kalbitz K, Kramer C, Leinweber P, Rethemeyer J, Schaeffer A, Schmidt MWI, Schwark L, Wiesenberg GLB. 2008. How relevant is recalcitrance for the stabilization of organic matter in soils? Journal of Plant Nutrition \& Soil Science 171(1):91-110.

Mishra HS, Rathore TR, Pant RC. 1997. Root growth, water potential, and yield of irrigated rice. Irrigation Science 17:69-75.

Nadeau MJ, Schleicher M, Grootes PM, Erlenkeuser H, Gottdang A, Mous DJW, Sarnthein JM, Willkomm H. 1997. The Leibniz-Labor AMS facility at the Christian-Albrechts University, Kiel, Germany. Nuclear Instruments and Methods in Physics Research B 123(14):22-30.
Nadeau MJ, Grootes PM, Schleicher M, Hasselberg P, Rieck A, Bitterling M. 1998. Sample throughput and data quality at the Leibniz-Labor AMS facility. Radiocarbon 40(1):239-45.

O’Brien BJ, Stout JD. 1978. Movement and turnover of soil organic matter as indicated by carbon isotope measurements. Soil Biology and Biochemistry 10(4): 309-17.

Pan G, Li L, Wu L, Zhang X. 2003. Storage and sequestration potential of topsoil organic carbon in China's paddy soils. Global Change Biology 10:79-92.

Paul EA, Follett RF, Leavitt SW, Halvorson A, Petersen GA, Lyon DJ. 1997. Radiocarbon dating for determination of soil organic matter pool sizes and dynamics. Soil Science Society of America Journal 61:1058-67.

Pessenda LCR, Gouveia SEM, Aravena R. 2001. Radiocarbon dating of total soil organic matter and humin fraction and its comparison with ${ }^{14} \mathrm{C}$ ages of fossil charcoal. Radiocarbon 43(2B):595-601.

Rethemeyer J, Kramer C, Gleixner G, John B, Yamashita T, Flessa H, Andersen N, Nadeau MJ, Grootes PM. 2005. Transformation of organic matter in agricultural soils: radiocarbon concentration versus soil depth. Geoderma 128(1-2):94-105.

Rice JA. 2001. Humin. Soil Science 166(11):848-57.

Rui W, Zhang W. 2010. Effect size and duration of recommended management practices on carbon sequestration in paddy field in Yangtze Delta Plain of China: a meta-analysis. Agriculture, Ecosystems and Environment 135:199-205.

Rumpel C, Kögel-Knabner I. 2011. Deep soil organic matter - a key but poorly understood component of terrestrial C cycle. Plant and Soil 338(1-2):143-58.

Scharpenseel HW, Becker-Heidmann P, Neue HU, Tsutsuki K. 1989. Bomb-carbon, ${ }^{14} \mathrm{C}$-dating and ${ }^{13} \mathrm{C}$ measurements as tracers of organic matter dynamics as well as of morphogenetic and turbation processes. The Science of the Total Environment 81/82:99-110.

Six J, Guggenberger G, Paustian K, Haumaier L, Elliott ET, Zech W. 2001. Sources and composition of soil organic matter fractions between and within soil aggregates. European Journal of Soil Science 52:607-18.

Stevenson FJ. 1994. Humus Chemistry - Genesis, composition, reactions. New York: John Wiley. 512 p.

Stuiver M, Polach HA. 1977. Discussion: reporting of ${ }^{14} \mathrm{C}$ data. Radiocarbon 19(3):355-63.

Tanji KK, Gao S, Scardaci SC, Chow AT. 2003. Characterizing redox status of paddy soils with incorporated rice straw. Geoderma 114(3-4):333-53.

Trumbore SE. 2000. Age of soil organic matter and soil respiration: radiocarbon constraints on belowground C dynamics. Ecological Applications 10(2):399-411.

Trumbore SE, Vogel JS, Southon JR. 1989. AMS ${ }^{14} \mathrm{C}$ measurements of fractionated soil organic matter: an approach to deciphering the soil carbon cycle. Radiocarbon 31(3):644-54.

Wade LJ, Fukai S, Samson BK, Ali A, Mazid MA. 1999. 


\section{Origin of Subsoil C in a Chinese Paddy Soil}

Rainfed lowland rice: physical environment and cultivar requirements. Field Crop Research 64:3-12.

Wang Y, Amundson R. 1996. Radiocarbon dating of soil organic matter. Quaternary Research 45:282-8.

Wissing L, Kölbl A, Vogelsang V, Fu JR, Cao ZH, KögelKnabner I. 2011. Organic carbon accumulation in a 2000-year chronosequence of paddy soil evolution. Catena 87:376-85.
Xu S, Shi X, Zhao Y, Yu D, Li C, Wang S, Tan M, Sun W. 2011. Carbon sequestration potential of recommended management practices for paddy soils of China, 1980-2050. Geoderma 166(1):206-13.

Yoshida S, Hasegawa S. 1982. The rice root system: its development and function. In: Drought Resistance in Crops with Emphasis on Rice. Manila: IRRI. p 97114. 